\title{
Molecular characterization of the mild Soil-borne wheat mosaic virus-Pol1 isolate
}

\author{
Katarzyna Trzmiel • Malgorzata Jeżewska • \\ Aleksandra Zarzyńska-Nowak
}

Accepted: 12 July 2017 / Published online: 31 August 2017

(C) The Author(s) 2017. This article is an open access publication

\begin{abstract}
Soil-borne wheat mosaic virus is the causal agent of leaf mosaic symptoms in cereals. The low virulence and limited propagation in infected plant tissues of a Polish isolate (SBWMV-Pol1) differ from the characteristics of other known isolates. The research aimed to clarify the effects of nucleotide sequence variability on the observed biological differences among the following three isolates: SBWMV-Pol1, SBWMVHeddesheim and SBWMV-SH1-3. Because of insufficient information regarding reference isolates, the RNAs from German isolates were sequenced for subsequent comparative analyses. Partial RNA1 and nearly complete RNA2 sequence for the Polish and two German isolates were obtained. Comparative analysis of received sequences with those of the corresponding fragments from other SBWMV isolates deposited in the GenBank database was carried out. The results of examined isolates confirmed: complete amino acid and nucleotide sequence identities for the replicase (REP) fragment 2 and the cysteine-rich protein, as well as complete amino acid and partial nucleotide sequence identities for the REP fragment $1(99.4-100 \%)$ and the
\end{abstract}

Electronic supplementary material The online version of this article (doi:10.1007/s10658-017-1296-4) contains supplementary material, which is available to authorized users.

K. Trzmiel $(\bowtie) \cdot$ M. Jeżewska $\cdot$ A. Zarzyńska-Nowak Institute of Plant Protection - National Research Institute, Władysława Węgorka 20, 60-318 Poznań, Poland e-mail: k.trzmiel@iorpib.poznan.pl coat protein $(87-100 \%)$, respectively. Differences in the amino acid and nucleotide sequences of the movement protein (MP) (98.7-99.6\% and $99.5 \%$ sequence identities, respectively) were also detected. The sequence of the -Pol1 isolate was very similar to those of the -SH1-3 and -Heddesheim isolates, with only one and three non-synonymous point mutations in the MP gene, respectively. Nevertheless, there were obvious differences in the biological properties of these isolates. Point mutations within the MP gene may have considerable consequences for symptom development.

Keywords SBWMV · Furovirus · Wheat - Deletion . Comparative analysis of sequences

Soil-borne wheat mosaic virus (SBWMV) is a furovirus responsible for mosaic symptoms in winter wheat and was first detected in the United States of America (McKinney 1923) followed by Europe approximately 40 years later (Canova 1964). The virus is transmitted by the soil-inhabiting plasmodiophorid, Polymyxa graminis Led. and by artificial mechanical inoculation. Infections of winter wheat by SBWMV can result in considerable yield losses (Palmer and Brakke 1975; Vallega and Autonell 1985). In Poland SBWMV was detected for the first time in 2012 (Trzmiel et al.). SBWMV-Poll isolate was not particularly virulent, and only produced semi-latent symptoms associated with a limited concentration of virus particles 
in plant tissues. Additionally, SBWMV-Poll differed biologically from the other described isolates (Trzmiel et al. 2012).

The study reported herein was conducted to clarify the contribution of nucleotide sequence variability to the observed biological differences among isolates. Experiments were conducted simultaneously to analyze SBWMV-Pol1, SBWMV-Heddesheim and SBWMV-SH1-3 because of the lack of available information regarding European isolates in the NCBI database. The sources of the SBWMV isolates were infested soils containing viruliferous spores of the vector. The SBWMV-Poll isolate was taken from Szelejewo in the southern part of the Greater Poland province (Trzmiel et al. 2012). The SBWMV-Heddesheim (from Heddesheim-BadenWürttemberg) and SBWMV-SH1-3 (from Cashagen-Schleswig-Holstein) isolates were provided by Prof. Thomas Kühne from the Julius Kühn Institut (Quedlinburg, Germany). Virus isolates were propagated in triticale (X Triticosecale Wittm. ex A. Camus) cv. Twingo and wheat (Triticum aestivum L.) cv. Brilliant plants grown in infested soils in climate chambers set to $17{ }^{\circ} \mathrm{C}$ (Shirako and Brakke 1984). After 2 months, all plants were examined using an enzyme-linked immunosorbent assay (ELISA) (LOEWE, Sauerlach, Germany). Isolates from infected plants were propagated mechanically. Symptomatic leaf homogenates in $0.1 \mathrm{M} \mathrm{K}_{2} \mathrm{HPO}_{4}$ were used for inoculation of wheat plants at 2-3-leaf stage and were maintained in climate chamber at optimal $17{ }^{\circ} \mathrm{C}$. Mechanical inoculation effectiveness were verified by ELISA test. The results indicated 30 and 21 infected out of 84 plants tested, respectively for SBWMV-Hedesheim and -SH1-3. Their optical density (OD) value ranged from 0.3 to 0.9 in comparison to average 0.05 for healthy plants. The same analysis for SBWMV-Poll isolate revealed only 9 infected plants out 128 tested. The OD value was lower and did not exceed 0.4. Additionally electron microscopic studies confirmed differences between German and Polish isolates. In plant sap infected with SBWMV-Heddesheim and SH1-3 numerous typical rod-shape virions were observed while analogical analysis for -Poll isolate revealed only single viral particles (data not shown). Polish isolate was hardly reproduced by mechanical inoculation therefore its propagation was conducted only by soil-transmission and German isolates were propagated mechanically. For molecular analyses SBWMV-Poll was collected from infected triticale cv. Twingo plants cultivated for more than 4 months and SBWMV-SH1-3 and SBWMV-Heddesheim isolates were obtained from wheat cv. Brilliant plants after mechanical passages (about 4 and 12 months after the first inoculation, respectively). Total RNA was extracted from approximately $100 \mathrm{mg}$ infected plant leaves using the NucleoSpin RNA Plant Kit (Macherey-Nagel, Düren, Germany) and stored at $-20{ }^{\circ} \mathrm{C}$. First-strand cDNA was synthesized using SuperScript ${ }^{\circledR}$ Reverse Transcriptase (Thermo Fisher Scientific, Waltham, MA, USA) with random hexamer primers following the manufacturer's instructions. The polymerase chain reaction (PCR) amplifications were conducted with a set of original primers covering most (99\%) of RNA1 coding sequence and the complete RNA2 sequence (Supplementary file). The primers were designed using the Primer3 program (http://frodo.wi.mit.edu/) based on the full-length RNA1 and RNA2 nucleotide sequences of US-Nebraska wild-type (NC002041 and L07938) (Rosen and Skaletski 2000). The PCR samples consisted of $1 \mu$ reverse transcription (RT) mixture, $1 \mu \mathrm{l} 10 \times$ AccuPrime $^{\mathrm{TM}}$ PCR Buffer II, $0.2 \mu \mathrm{l}$ primer $\operatorname{mix}(10 \mu \mathrm{mol} / \mu \mathrm{l}$ each $), 0.25 \mu \mathrm{l}$ AccuPrime $^{\mathrm{TM}}$ Taq DNA Polymerase (Thermo Fisher Scientific), and sterile Milli-Q water up to a final volume of $10 \mu \mathrm{l}$. The PCR conditions were as follows: $94{ }^{\circ} \mathrm{C}$ for $2 \mathrm{~min} ; 35$ cycles of $94{ }^{\circ} \mathrm{C}$ for $30 \mathrm{~s}$, $55^{\circ} \mathrm{C}$ for $30 \mathrm{~s}, 68^{\circ} \mathrm{C}$ for $30-90 \mathrm{~s}$ (depending on the expected amplicon size); $68{ }^{\circ} \mathrm{C}$ for $5 \mathrm{~min}$. Amplicons of the expected size were obtained for most primer pairs, except those amplifying the REPencoding gene on RNA1. Along with the expected 1690-bp amplicon, SBW2-F2/SBW2-R2 primer pair produced additional shorter PCR products. All amplified products were excised from the agarose gel and purified using the Wizard®SV Gel and PCR Clean-Up System (Promega, Madison, WI, USA). The purified fragments were ligated into the pGEM-T Easy vector (Promega), and then inserted into Escherichia coli TOP10 competent cells (Thermo Fisher Scientific). Plasmid DNA was isolated using the NucleoSpin® Plasmid (NoLid) kit (Macherey-Nagel). At least three clones for each fragment were sequenced at Genomed S.A. (Warsaw, Poland) using the M13-F and M13-R primers. The nucleotide sequences were analyzed using the 

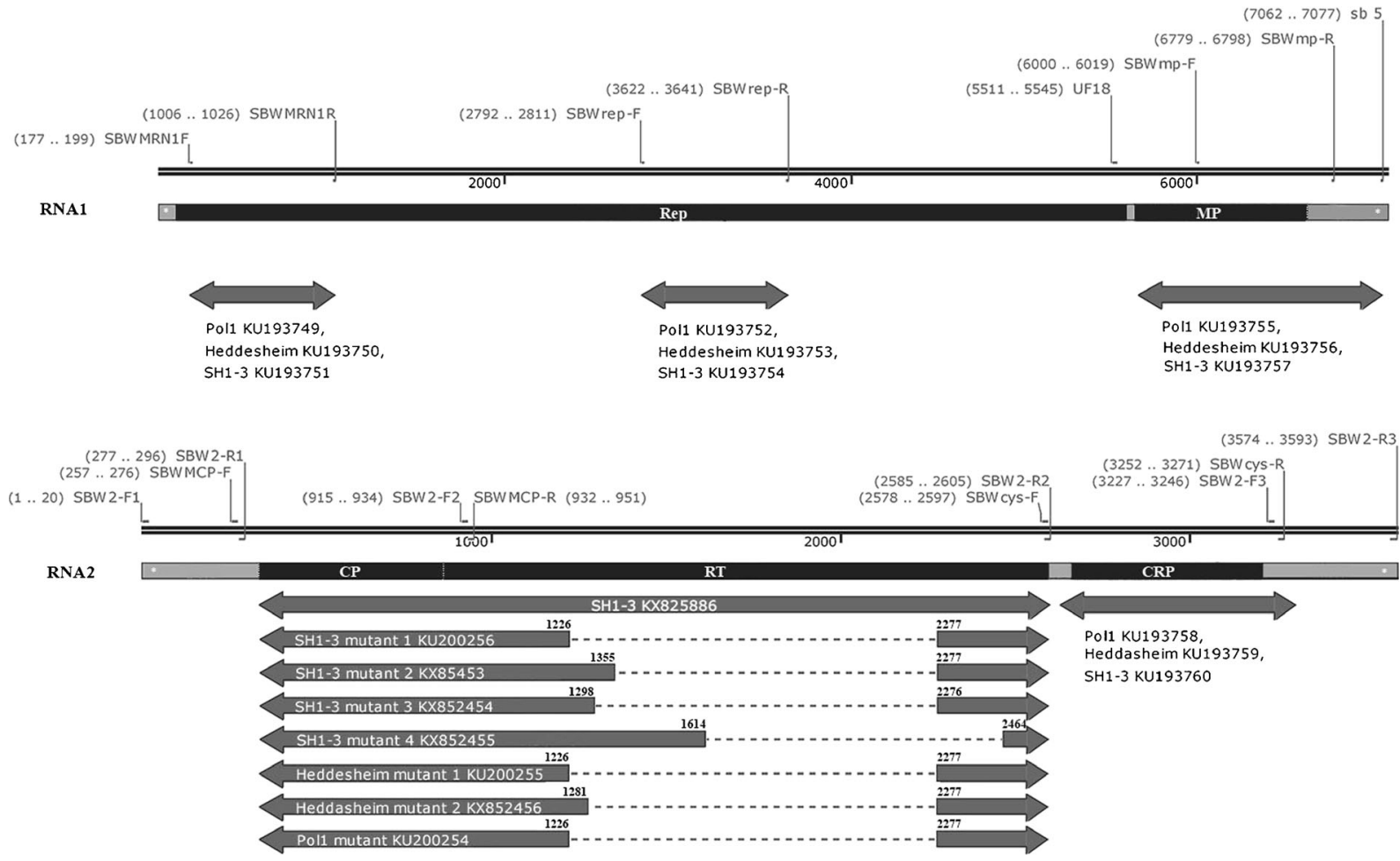

Fig. 1 Schematic representation of the Soil-borne wheat mosaic virus genome. Dark boxes represent the replicase (REP) and movement protein (MP) gene sequences on RNA1, as well as the capsid read-through (CP-RT) and cysteine-rich protein (CRP) gene sequences on RNA2. Grey boxes with white asterisks

Standard Nucleotide BLAST online tool (blastn; http://blast.ncbi.nlm.nih.gov/Blast.cgi), after which they were compiled and edited using the BioEdit program (Hall 1999). The sequences were deposited in the NCBI GenBank database. Details regarding primer usage as well as gene fragment positions and their accession numbers are presented in Fig. 1, which was generated using the SnapGene Viewer program (http://www.snapgene.com).

The objective of this investigation was to obtain complete or almost complete genome sequence. Nucleotide sequence analysis of SBWMV RNA1 and RNA2 could not be completed because of the failure to determine the full coding sequence of the replicase (REP) gene of analyzed isolates. The experiments showed the lack of RT-PCR specific products with three out of five tested primers pairs (probably caused by incompatibility between the primers and genome sequence or by partial degradation of 5'terminus RNA1 of SBWMV). The represent untranslated regions. The primers used to amplify fragments of SBWMV isolates -Pol1, -SH3-1, and -Heddesheim (twosided arrows) are indicated. Two-sided arrows with deleted regions represent different CP-RT gene mutants. Accession numbers are provided for genome fragments

sequencing of the amplicons for SBWMV RNA1 enabled the determination of only partial coding sequence (i.e. two fragments, $30 \%$ ) of the REP gene and the complete coding sequence of the movement protein (MP) gene. The same analysis for RNA2 revealed the complete coding sequence of the genes encoding the capsid read-through (CP-RT) protein (for SBWMVSH1-3) and cysteine-rich protein (CRP) (Fig. 1). An analysis of nucleotide sequences revealed the high frequency of deletions in the RNA2 CP-RT gene region in all studied SBWMV isolates. The spontaneous deletions are likely associated with the duration of the growth period (i.e., over 4 months) for systemically infected plants at $17^{\circ} \mathrm{C}$ (Shirako and Brakke 1984) or at $25^{\circ} \mathrm{C}$ (Mansournia 2008), as well as with serial passage experiments (Yamamiya et al. 2005). There are common and have been detected in CP-RT genes from Oat golden stripe virus (OGSV; genus: Furovirus), Potato moptop virus (genus: Pomovirus), and Beet necrotic yellow 
vein virus (genus: Benyvirus) (Diao et al. 1999). The exact position of each deletion was determined by sequencing multiple clones using the SBWMCP-F/ SBWMCP-R and SBW2-F2/SBW2-R2 primer pairs (Fig. 1). Four different deletion mutants were detected for SBWMV-SH1-3, with the dominant form being SBWMV-SH1-3-mutant1. There were two different mutants for SBWMV-Heddesheim, and only a single RNA2 mutant for SBWMV-Pol1 (Fig. 1). Additionally, our results suggest the presence of one best-adapted inframe deletion mutant leading to the loss of 350 amino acids from the CP-RT protein for all isolates. We observed that SBWMV-Pol1 with deletions in the RNA2 sequence did not induce more severe symptoms than wild-type viral strains under field conditions. This result is consistent with those of an earlier study (Yamamiya and Shirako 2000), in which the authors concluded that variations in symptom severities were not simply due to deletions in the CP-RT gene region, as it had been previously suggested (Shirako and Brakke 1984, Chen et al. 1994).

Existing nucleotide sequences of SBWMV cover mostly RNA2 genome fragment. There are only two complete RNA1 and RNA2 genome sequences in the GenBank database. The nucleotide and amino acid sequences of the analyzed isolates were compared with the corresponding sequences of other known SBWMV isolates (Tables 1 and 2). Previous studies (Diao et al. 1999, Shirako et al. 2000) demonstrated that the RNA polymerase domain situated in 3' REP gene was highly conserved among RNA-1 encoded proteins. Our results, like those published by Koenig et al. (2002, 2003) revealed very close relationships (97.4-100\% amino acid sequence identity) within the helicase domain (REP fragment 2) of SBWMV isolates. Analogically on RNA2 the CP amino acid sequences were almost identical among all isolates (sequence identity: 98.8$100 \%)$. The results are compatibled with those received by Shirako and Wilson (1993). The genome region containing the CRP gene, which is responsible for viral pathogenicity, included mutations that resulted in some amino acid sequence variability (sequence identity: 96$100 \%$ ). The genomic variability leading to amino acid sequence differences was also detected for the MP, which enables the virus to move in infected plants (sequence identity: 97.5-99.6\%) (Table 1).

A comparison of nucleotide sequences revealed a sequence identity of $87.4-100 \%$ for the REP gene, $89.7-99.5 \%$ for the MP gene, $86.4-100 \%$ for the CP gene, and $93.5-100 \%$ for the CRP gene (Table 1). Most of the nucleotide sequence changes were synonymous point mutations, with 100 in the REP gene, 86 in the MP gene, 71 in the CP gene, and 28 in the CRP gene. There were considerably fewer non-synonymous mutations, with 7,10 , and 5 in the REP, MP, and CRP genes, respectively (Table 2).

Phylogenetic analyses were conducted for the analyzed and previously characterized SBWMV isolates, as well as for selected SBCMV, Chinese wheat mosaic virus (CWMV), and OGSV isolates from the GenBank database. The ClustalW program was used for multiple sequence alignments (Thompson et al. 1994). The phylogenetic relationships among sequences were analyzed using the maximum likelihood algorithm, and the optimal DNA/protein models were selected with the MEGA 6.1 program (Tamura et al. 2013). Bootstrap values were calculated using 1000 random replicates. Phylogenetic trees were prepared using TreeExplorer in the MEGA 6.1 program. The tree, which was based on the nucleotide sequence of $\mathrm{CP}$ gene, included the following two main clades: (1) European isolates: -Pol1, -Heddesheim, -De1, and -French; American isolates: -Okl-1, -NE, and -US-lab1; (2) European isolate: -SH1-3; American isolates: -NY, -Illinois, $-\mathrm{OH}$, and -Urbana (Fig. 2). It is corresponding to molecular analysis where SBWMVPoll sequence was highly similar to that of three American isolates: -NE, -Nebraska US-lab1, and Okl-1 (i.e., 97.7, 97.7, and 98.8\% sequence identities, respectively). Our results were consistent with previously reported data for these isolates, which were included in the Nebraska-like group (Koenig et al. 2002; Trzmiel et al. 2012). In contrast, we observed an $87 \%$ nucleotide sequence identity between the SBWMV-SH1-3 and -Poll isolates. The $\mathrm{CP}$ gene sequence of $-\mathrm{SH} 1-3$ was most similar to that of $-\mathrm{OH},-\mathrm{NY},-$ Urbana, and -Illinois isolates from the New-York-like group (i.e., 98.8, 98.6, 98.3, and $98.4 \%$ sequence identities, respectively). These findings were in agreement with those of Ziegler et al. (2013). However, our sequence comparison results for the other SBWMV genes (i.e., REP, MP, and CRP genes) revealed the -Poll, Heddesheim, and -SH1-3 isolates were more closely related to the isolates of the New York-like group than to the Nebraska-like isolates. Moreover, the phylogenies of the CRP (Fig. 3) and MP (data 
Table 1 Percentage of nucleotide/amino acid sequences identity of different genome regions between - Poll and other known SBWMV isolates

\begin{tabular}{|c|c|c|c|c|c|}
\hline $\begin{array}{l}\text { SBWMV } \\
\text { Isolate }\end{array}$ & $\begin{array}{l}\text { Replicase protein } \\
\text { fragment } 1 \\
\text { SBWMV-Pol1 }\end{array}$ & $\begin{array}{l}\text { Replicase protein } \\
\text { fragment } 2 \\
\text { SBWMV-Pol1 }^{+}\end{array}$ & $\begin{array}{l}\text { Movement } \\
\text { protein }(\mathrm{MP}) \\
\text { SBWMV-Pol1 }^{+}\end{array}$ & $\begin{array}{l}\text { Coat protein }(\mathrm{CP}) \\
\text { SBWMV-Pol1 }^{+}\end{array}$ & $\begin{array}{l}\text { Cysteine-rich } \\
\text { protein }(\mathrm{CRP}) \\
\text { SBWMV-Pol1 }^{+}\end{array}$ \\
\hline - Heddesheim ${ }^{+}$ & $100 / 100$ & $100 / 100$ & 99.5 / 98.7 & $100 / 100$ & $100 / 100$ \\
\hline$-\mathrm{SH} 1-3^{+}$ & $99.4 / 100$ & $100 / 100$ & 99.5 / 99.6 & $87 / 100$ & $100 / 100$ \\
\hline$-D e 1^{*}$ & - & 87.4 / 97.4 & - & $100 / 100$ & $93.9 / 97.1$ \\
\hline$-\mathrm{NE}^{*}$ & 87.4 / 98.2 & $87.9 / 98.9$ & 89.7 / 97.5 & $97.7 / 100$ & $93.7 / 96.5$ \\
\hline -Nebraska US-lab1 ${ }^{*}$ & - & - & - & $97.7 / 98.8$ & $93.5 / 96$ \\
\hline$-N Y^{*}$ & - & $99.6 / 100$ & $98.4 / 99$ & $86.8 / 100$ & $97.3 / 98.8$ \\
\hline -Urbana* & - & - & - & 86.4 / 98.8 & - \\
\hline$-\mathrm{Okl}-1^{*}$ & - & - & - & $98.8 / 100$ & $93.5 / 97.1$ \\
\hline -Illinois ${ }^{*}$ & - & - & - & $87 / 100$ & - \\
\hline$-\mathrm{OH}^{*}$ & $99.0 / 100$ & $99.3 / 100$ & $99.5 / 99.6$ & $86.6 / 100$ & $96.7 / 98.2$ \\
\hline
\end{tabular}

+- GenBank accesion numbers are given on Fig. 1

*- GenBank accession numbers are given in the following order: -De (AF519798-AF519800); -NE (NC002041, L07938); -NebraskaUSlab1 (D86320); -NY (AY016007, AF361641-42, AY016008); -Urbana (HM133583); -Okl-1 (X81639); -Illinois (AB002812); -OH (KT736088-89

not shown) genes demonstrated that -Pol1, -Heddesheim, and -SH1-3 were clustered with $\mathrm{NY}$ and $-\mathrm{OH}$ isolates.

Our data revealed the significant genetic similarity among the studied isolates. The differences between SBWMV-Poll and -Heddesheim included one synonymous and three non-synonymous point mutations in the MP gene while the variability between -Poll and -SH13 consisted of three synonymous point mutations in fragment 1 of the REP gene, one non-synonymous and three synonymous point mutations in the MP gene and 69 synonymous point mutations in the $\mathrm{CP}$ gene (Table 2). Despite the considerable similarities in obtained genomic sequences among studied SBWMV isolates there are important biological differences between German isolates and Polish one. SBWMV-Poll is characterized by inducing only mild symptoms, low virulence and limited concentration in infected plant tissues.

Although infectious SBWMV clones have been used to study the CP-RT (Yamamiya and Shirako 2000) and

Table 2 A summary of non-synonymous (NS) and synonymous (S) mutations in nucleotide sequence of different genome regions between Polish and other known SBWMV isolates

\begin{tabular}{|c|c|c|c|c|c|c|c|c|c|c|}
\hline \multirow[t]{4}{*}{$\begin{array}{l}\text { SBWMV } \\
\text { Isolate }\end{array}$} & \multicolumn{2}{|c|}{$\begin{array}{l}\text { Replicase protein } \\
\text { fragment } 1\end{array}$} & \multicolumn{2}{|c|}{$\begin{array}{l}\text { Replicase protein } \\
\text { fragment } 2\end{array}$} & \multicolumn{2}{|c|}{$\begin{array}{l}\text { Movement protein } \\
\text { (MP) }\end{array}$} & \multicolumn{2}{|c|}{$\begin{array}{l}\text { Coat protein } \\
(\mathrm{CP})\end{array}$} & \multicolumn{2}{|c|}{$\begin{array}{l}\text { Cysteine-rich protein } \\
\text { (CRP) }\end{array}$} \\
\hline & \multicolumn{2}{|c|}{ SBWMV-Pol1 } & \multicolumn{2}{|c|}{ SBWMV-Pol1 } & \multicolumn{2}{|c|}{ SBWMV-Pol1 } & \multicolumn{2}{|c|}{ SBWMV-Pol1 } & \multicolumn{2}{|c|}{ SBWMV-Pol1 } \\
\hline & \multicolumn{10}{|c|}{ Mutations } \\
\hline & NS & $\mathrm{S}$ & NS & $\mathrm{S}$ & NS & $\mathrm{S}$ & NS & $\mathrm{S}$ & NS & $\mathrm{S}$ \\
\hline - Heddesheim & 0 & 0 & 0 & 0 & 3 & 1 & 0 & 0 & 0 & 0 \\
\hline - SH1-3 & 0 & 3 & 0 & 0 & 1 & 3 & 0 & 69 & 0 & 0 \\
\hline - De1 & - & - & 5 & 69 & - & - & 0 & 0 & 4 & 26 \\
\hline$-\mathrm{NE}$ & 7 & 100 & 2 & 69 & 10 & 86 & 0 & 12 & 5 & 28 \\
\hline$-N Y$ & - & - & 0 & 2 & 3 & 2 & 0 & 70 & 1 & 13 \\
\hline$-\mathrm{OH}$ & 0 & 7 & 0 & 4 & 1 & 4 & 0 & 71 & 2 & 15 \\
\hline
\end{tabular}


Fig. 2 Maximum likelihood tree based on the CP gene nucleotide sequences of SBWMV, SBCMV, CWMV, and OGSV isolates. The numbers at each major node indicate bootstrap values out of 1000 replicates (provided only when $>50 \%$ ). The scale bar represents the number of substitutions per base, and corresponds to the nucleotide diversity among taxa. The analyzed isolates are indicated (i.e., Polish isolate: red dot; German isolates: black dots)

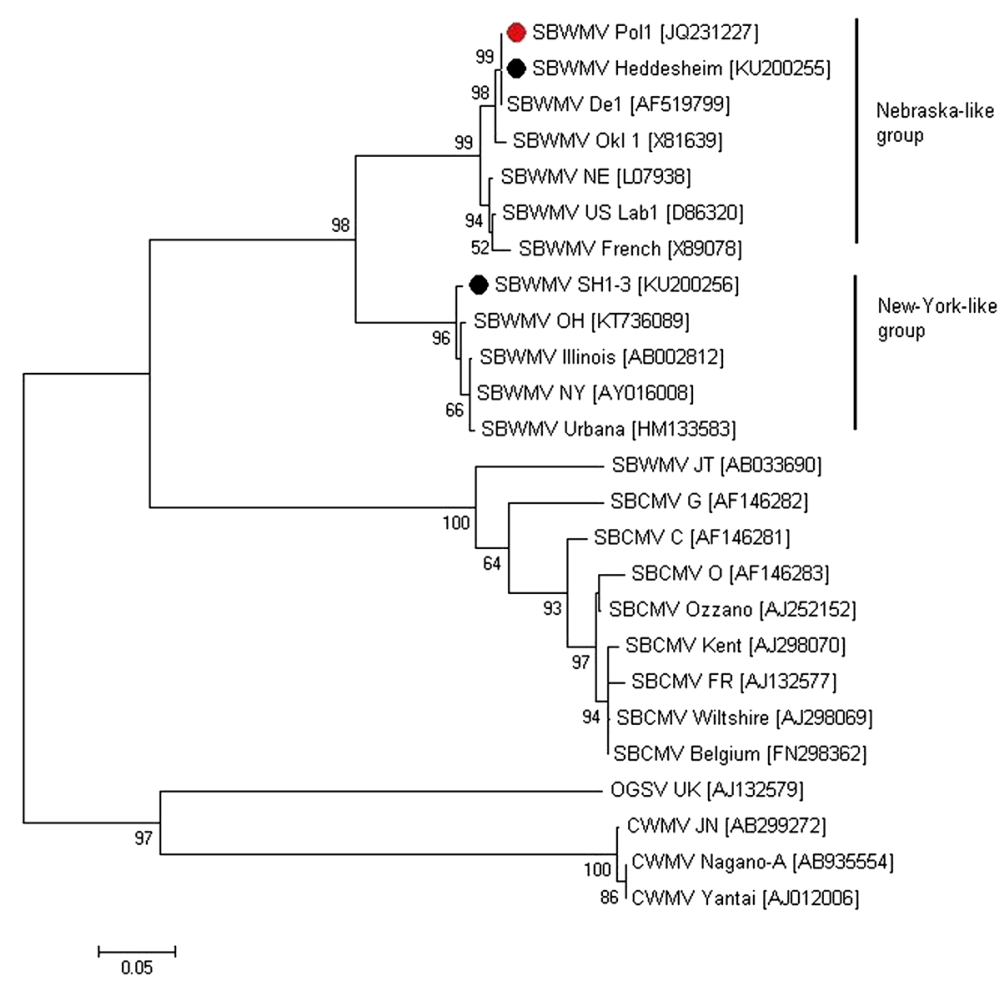

CRP (Jarugula et al. 2016) genes, the pathogenicity determinants have not been identified yet. However, even single amino acid substitutions can affect viral pathogenicity as it was previously presented. For example, a point mutation in TGB3, which is associated with viral movement, can convert the mild Pepino mosaic virus pathotype into a necrotic pathotype (HasiówJaroszewska et al. 2011). Kwak et al. (2016) revealed that a symptom determinant was located in the RNA2 of Broad bean wilt virus 2, which includes the MP gene coding sequence. Wieczorek and ObrępalskaStęplowska (2016) confirmed the importance of a single
Fig. 3 Maximum likelihood tree based on the CRP gene nucleotide sequences of SBWMV, SBCMV, CWMV, and OGSV isolates. The numbers at each major node indicate bootstrap values out of 1000 replicates (provided only when $>50 \%$ ). The scale bar represents the number of substitutions per base, and corresponds to the nucleotide diversity among taxa. The analyzed isolates are indicated (i.e., Polish isolate: red dot; German isolates: black dots)

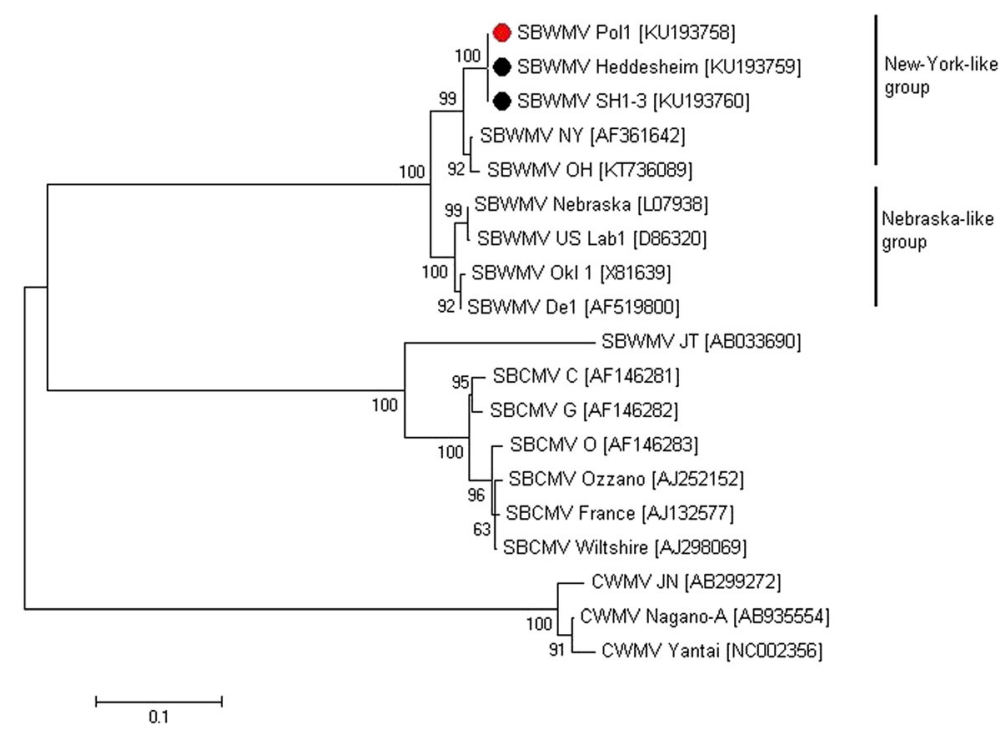


point mutation within the MP gene for Tomato torrado virus infections and symptom development. Additionally, point mutations in the MP gene can induce systemic SBWMV infections at higher temperatures (e.g., $25^{\circ} \mathrm{C}$ ) (Mansournia 2008) and alter the type of Brome mosaic virus infection from local to systemic (Trzmiel et al. 2016).

The comparative analysis of the MP protein revealed differences for the 28th amino acid, namely an alanine, occurring in all other SBWMV isolates was replaced by a valine in SBWMV-Poll. This difference was due to a change in the 83rd nucleotide from a cytosine to a thymine. However, elucidating the function of this point mutation requires additional research. Based on our data, investigations of pathogenicity determinants within the MP gene should be continued.

Acknowledgements The authors thank Prof. Thomas Kühne from The Julius Kühn-Institut (Quedlinburg, Germany) for providing the German isolates used in this study. Special thanks are also extended to members of the Danko Plant Breeding Station in Szelejewo for their help and to Marzena Lewandowska for her technical assistance.

Authors' contributions KT designed the research, performed laboratory experiments, gathered and analyzed the data, and wrote the manuscript. MJ designed the research and revised the manuscript. A ZN performed phylogenetic analyses and revised manuscript. All authors read and approved the final manuscript.

\section{Compliance with ethical standards}

Conflict of interest The authors declare that they have no conflict of interest.

Ethical approval This article does not contain any studies with human participants or animals performed by any of the authors.

Open Access This article is distributed under the terms of the Creative Commons Attribution 4.0 International License (http:// creativecommons.org/licenses/by/4.0/), which permits unrestricted use, distribution, and reproduction in any medium, provided you give appropriate credit to the original author(s) and the source, provide a link to the Creative Commons license, and indicate if changes were made.

\section{References}

Canova, A. (1964). Ricerche sulle malattie da virus delle Graminacae. I. Mosaico del Frumento transmissibile attraverso il terreno. Phytopathologia Mediterranea, 3, 86-94.
Chen, J., MacFarlane, S.A., Wilson, T.M.A. (1994). Detection and sequence analysis of a spontaneous deletion mutant of soilborne wheat mosaic virus RNA2 associated with increased symptom severity. Virology, 202.

Diao, A. P., Chen, J. P., Gitton, F., Antoniw, J. F., Mullins, J., Hall, A. M., \& Adams, M. J. (1999). Sequences of European wheat mosaic virus and Oat golden stripe virus and genome analysis of the genus Furovirus. Virology, 261, 331-339.

Hall, T. A. (1999). BioEdit: a user-friendly biological sequence alignment editor and analysis program for Windows 95/98/ NT. Nucleic Acids Symposium Series, 41, 95-98.

Hasiów-Jaroszewska, B., Borodynko, N., Jackowiak, P., Figlerowicz, M., \& Pospieszny, H. (2011). Single mutation converts mild pathotype of the Pepino mosaic virus into necrotic one. Virus Research, 159, 57-61.

Jarugula, S., Charlesworth, S. R., Qu, F., \& Stewart, L. R. (2016). Soil-borne wheat mosaic virus infectious clone and manipulation for gene-carrying capacity. Archives of Virology, 161(8), 2291-2297.

Koenig, R., Bergstrom, G. C., Gray, S. M., \& Loss, S. (2002). A New-York isolate of Soil-borne wheat mosaic virus differs considerably from the Nebraska type strain in the nucleotide sequences of various coding regions but not in the deduced amino acid sequences. Archives of Virology, 147, 617-625.

Koenig, R., \& Huth, W. (2003). Natural infection of wheat by the type strain of Soil-borne wheat mosaic virus in a field in Southern Germany. European Journal of Plant Pathology, 109, 191-193.

Kwak, H. R., Lee, Y. J., Kim, M. K., Kim, J. S., Choi, H. S., \& Seo, J. K. (2016). A determinant of disease symptom severity is located in RNA2 of broad bean wilt virus 2. Virus Research, 211, 25-28.

Mansournia, M. R. (2008). An analysis of spontaneous deletion site in RNA2 of a new variant of Soil-borne wheat mosaic virus systemically infects plants at high temperatures. Asian Journal of Plant Sciences, 7(8), 742-746.

McKinney, H. H. (1923). Investigations on the rosette disease of wheat and its control. Journal of Agricultural Research, 23, 771-800.

Palmer, L., \& Brakke, M. (1975). Yield reduction in winter wheat infected with soilborne wheat mosaic virus. Plant Disease Reporter, 59, 469-471.

Rosen, S., \& Skaletski, H. J. (2000). Primer3 on the WWW for general use and for biologist programmers. In S. Krawetz \& S. Misenes (Eds.), Bioinformatics Methods and Protocols: Methods in Molecular Biology (pp. 365-386). Totova: Humana Press.

Shirako, Y., \& Brakke, M. (1984). Spontaneous deletion mutation of soil-borne wheat mosaic virus RNAII. Journal of General Virology, 65, 855-858.

Shirako, Y., \& Wilson, T. M. A. (1993). Complete nucleotide sequence and organization of the bipartite RNA genome of Soil-borne wheat mosaic virus. Virology, 195, 16-32.

Shirako, Y., Suzuki, N., \& French, R. C. (2000). Similarity and divergence among viruses in the genus Furovirus. Virology, 270, 201-207.

Tamura, K., Stecher, G., Peterson, D., Filipski, A., \& Kumar, S. (2013). MEGA6: Molecular Evolutionary Genetics Analysis Version 6.0. Molecular Biology and Evolution, 30, 27252729. 
Thompson, J. D., Higgins, D. G., \& Gibson, T. J. (1994). CLUSTAL W: improving the sensitivity of progressive multiple sequence alignment through sequence weighting, position-specific gap penalties and weight matrix choise. Nucleic Acids Research, 22(22), 4673-4680.

Trzmiel, K., Jeżewska, M., \& Zarzyńska, A. (2012). First report of Soil-borne wheat mosaic virus (SBWMV) - infecting triticale in Poland. Journal of Phytopathology, 160(10), 614-616.

Trzmiel, K., Zarzyńska-Nowak, A., Lewandowska, M., \& Szydło, W. (2016). Identification of new Brome mosaic virus (BMV) isolates systemically infecting Vigna unguiculata L. European Journal of Plant Pathology, 145, 233-238.

Vallega, V., \& Rubies-Autonell, C. (1985). Reactions of Italian Triticum durum cultivars to soilborne wheat mosaic. Plant Disease, 69, 64-66.

Wieczorek, P., \& Obrępalska-Stęplowska, A. (2016). A single amino acid substitution in movement protein of tomato torrado virus influences ToTV infectivity in Solanum lycopersicon. Virus Research, 213, 32-36.

Yamamiya, A., \& Shirako, Y. (2000). Construction of full-length cDNA clones to Soil-borne wheat mosaic virus RNA1 and RNA2, from which infectious RNAs are transcribed in vitro: virion formation and systemic infection without expression of the N-terminal and C-terminal expression to the capsid protein. Virology, 277, 66-75.

Yamamiya, A., Miyanishi, M., \& Shirako, Y. (2005). Stable deletions arising in the readthrough region of Soil-borne wheat mosaic virus RNA2 define the 5' limit of the functional promoter for the p19 subgenomic RNA. Archives of Virology, 150, 1871-1884.

Ziegler, A., Golecki, B., \& Kastirr, U. (2013). Occurrence of the New York strain of Soil-borne wheat mosaic virus in Northern Germany. Journal of Phytopathology, 161, 290292. 